Terbit online pada laman : http://teknosi.fti.unand.ac.id/

Jurnal Nasional Teknologi dan Sistem Informasi

ISSN (Print) 2460-3465 | ISSN (Online) 2476-8812

Artikel Penelitian

\title{
Pembangunan Sistem Informasi Manajemen Ujian pada Jurusan Sistem Informasi Universitas Andalas
}

\author{
Husnil Kamil ${ }^{a}{ }^{*}$ Fauzan Pramulia ${ }^{a}$ \\ ${ }^{a}$ Jurusan Sistem Informasi, Fakultas Teknologi Informasi, Universitas Andalas
}

\section{INFORMASI ARTIKEL}

Sejarah Artikel:

Diterima Redaksi: 14 Juli 2019

Revisi Akhir: 16 Desember 2019

Diterbitkan Online: 15 Januari 2020

\section{KATA KUNCI}

Manajemen Ujian

Sistem Informasi

Mobile

Web

Java

\section{KORESPONDENSI}

E-mail: husnilk@it.unand.ac.id

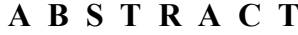

Pelaksanaan ujian konvensional masih umum diterapkan di kampus dan sekolah, termasuk Jurusan Sistem Informasi Universitas Andalas. Ujian konvensional merupakan ujian yang menggunakan media kertas. Pelaksanaan ujian secara konvensional memiliki beberapa kekurangan yaitu membutuhkan biaya yang tidak sedikit. Dalam satu kali periode ujian Jurusan Sistem Informasi memerlukan lebih dari 5 rim kertas lembar jawaban dan biaya perbanyakan lembaran soal. Selain itu untuk beberapa jenis soal tertentu, ujian konvensional rentang terhadap kecurangan peserta ujian. Ujian secara konvensional juga membutuhkan waktu pemeriksaan hasil ujian yang lama. Solusi dari permasalahan tersebut adalah mengadakan ujian melalui perangkat elektronik dengan menggunakan platform web dan mobile. Perangkat elektronik mengurangi tingkat pengadaan kertas. Penggunaan perangkat mobile sebagai media untuk pelaksanaan ujian akan mengurangi biaya, karena yang diperlukan hanya sebuah perangkat mobile untuk semua jenis ujian. Penelitian ini bertujuan untuk membangun sebuah Sistem Informasi Manajemen Ujian yang menggunakan perangkat teknologi informasi dalam pengelolaan dan pelaksanaan ujian. Metode penelitian yang digunakan dalam penelitian ini mengadopsi pengembangan perangkat lunak waterfall. Tahapan penelitian yang dilaksanakan meliputi requirements definitions, system and software design, implementation, dan system testing. Bahasa pemrograman yang digunakan adalah Java, PHP dan MYSQL sebagai databasenya. Implementasi dari sistem informasi ini meliputi manajemen ujian, manajemen soal ujian dan manajemen data dosen serta mahasiswa yang nantinya akan menghasilkan keluaran nilai ujian. Penelitian ini telah berhasil membangun sebuah sistem informasi manajemen ujian sebagai solusi dari penggunaan kertas, meminimalisir waktu dalam pemeriksaan ujian serta tindak kecurangan pada pelaksanaan ujian.

\section{PENDAHULUAN}

Ujian merupakan satu proses yang sistematik untuk mengukur pencapaian pelajar yang biasanya dibuat secara tertulis. Ujian dapat dianggap sebagai proses penyerahan set soal yang perlu dijawab, atau satu set instrumen bersama satu prosedur yang sistematik bagi mengukur sampel tingkah laku atau perubahan seseorang individu atau pelajar. Ujian adalah satu prosedur yang sistematik untuk memperhatikan perlakuan atau tingkah laku seseorang individu dan menjelaskannya dengan batuan skala bernomor, atau satu sistem yang berkategori [1]. Pengukuran ini merupakan suatu proses bagi penguji untuk menentukan perubahan dan membuat pertimbangan nilai. Melalui ujian, seseorang penguji dapat mengetahui tentang pencapaian objek, kaedah mengajar dan keberkesanan sebuah kurikulum.

Pelaksanaan ujian di Jurusan Sistem Informasi Universitas Andalas masih menggunakan cara konvensional yaitu ujian tertulis. Kekurangan dari metode ujian tertulis ini adalah biaya yang dibutuhkan. Penggunaan kertas sebagai media ujian membutuhkan biaya yang tidak sedikit. Kertas juga media yang rentan rusak dan hilang. Selain itu, untuk jenis soal tertentu yaitu pilihan ganda dan jawaban singkat, ujian tertulis rentan terhadap tindak curang peserta ujian. Beberapa jenis ujian tertentu memiliki proses yang tidak sederhana seperti Ujian Tengah Semester (UTS) dan Ujian Akhir Semester (UAS). Ujian ini 
membutuhkan proses verifikasi dan validasi dari ketua Gugus Kendali Mutu (GKM) dan Ketua Jurusan sebagai bagian proses penjaminan mutu di Jurusan Sistem Informasi. Proses validasi dan verifikasi soal ini membuat proses pengelolaan ujian menjadi lebih rumit.

Dari beberapa persoalan yang telah dikemukakan sebelumnya maka diperlukan solusi untuk mengatasi persoalan tersebut. Teknologi Informasi sebagai salah satu teknologi yang dapat membantu hidup manusia dapat dimanfaatkan dalam dunia pendidikan seperti kampus dan sekolah. Penelitian terkait penggunaan teknologi informasi dalam ujian pernah dilakukan. Salah satu diantaranya adalah dalam hal rancang bangun modul back soal dan generator soal. Penelitian ini dilakukan oleh Arnold dan Maria Irmina dan menghasilkan aplikasi yang memfasilitasi pengelolaan soal-soal dan aset-aset yang sudah dibuat sebelumnya. Namun, fungsi yang dimiliki oleh aplikasi ini terbatas pada input soal ke dalam sistem dan menghasilkan soalsoal yang telah diinputkan [2].

Dalam hal pelaksanaan ujian, penggunaan komputer dinilai tidak efektif jika digunakan dalam kelas. Hal ini dikarenakan laptop atau komputer ukurannya yang cukup besar dan kemampuan baterai yang tidak merata. Alternatif lainnya adalah dengan menggunakan perangkat smartphone sebagai perangkat ujian dikarenakan fungsi yang dimiliki oleh smartphone hampir sama dengan komputer. Perangkat smartphone memiliki performa dan kecepatan akses yang tinggi dibandingkan dengan komputer atau laptop[3]. Selain itu telepon genggam juga membutuhkan konsumsi daya yang cukup rendah sehingga dapat selalu aktif saat ujian berlangsung[4]. Oleh karena itu fitur akses mobile merupakan fitur yang penting untuk diimplementasikan pada sistem informasi ujian. Terdapat penelitian yang bertujuan untuk memanfaatkan smartphone sebagai alat bantu Pendidikan. Diantaranya penelitian yang dilakukan oleh Jason Potts, NS. Moore dan S. Sukittanon untuk mengembangkan aplikasi mobilelearning pada platform Android dan iOS. Aplikasi yang dikembangkan digunakan pada mata kuliah Electrical Engineering di Universitas Tennessee. Aplikasi ini memiliki fitur kuis untuk menaksir pemahaman mahasiswa terkait materi yang diberikan. Penelitian tersebut tidak memfokuskan pada ujian yang dilakukan karena aplikasi tersebut lebih difokuskan untuk membantu mahasiswa mempelajari materi [5]

Pemanfaatan telepon genggam sebagi perangkat dalam evaluasi belajar juga telah pernah diteliti sebelumnya. Reggie Davidrajuh melakukan penelitian untuk mengembangkan aplikasi untuk mengevaluasi performance siswa di dalam kelas. Siswa menggunakan aplikasi mobile untuk menjawab pertanyaan. Aplikasi yang dikembangkan berupa aplikasi Java yang menggunakan Bluetooth sebagai saluran transmisi data antara client dan server [6]. Penelitian lainnya terkait aplikasi mobile untuk ujian juga telah dilakukan oleh Joan Lu et al. pada tahun 2011. Penelitian yang dilakukan lebih difokuskan kepada database yang digunakan dalam aplikasi Mobile Exam System [7]. M Husni Syahbani juga melakukan penelitian menggunakan perangkat mobile. Penelitian ini berfokus pada simulasi ujian yang dilakukan dengan membahas soal-soal yang ada pada aplikasi. Penelitian ini tidak memfokuskan pada sistem informasi dari pengelolaan ujian[8]. Banyaknya penelitian yang telah dilakukan menunjukkan bahwa telepon genggam memiliki potensi yang sangat besar dalam dunia pendidikan.

Perangkat smartphone merupakan perangkat yang memiliki system operasi di dalamnya. Saat ini terdapat 2 jenis system operasi smartphone yang populer yaitu Android dan IOS. Android memiliki pangsa pasar yang besar sekitar $84,8 \%$, IOS $15,1 \%$ dan lainnya $0,1 \%$. Survei tersebut dikutip dari website resmi dengan data IDC tahun 2017 [9]. Android adalah sebuah sistem operasi untuk mobile berbasis Linux yang mencakup sistem operasi, middleware dan aplikasi. Android menyediakan platform yang terbuka bagi para pengembang untuk menciptakan aplikasi mereka. Android merupakan generasi baru platform mobile, platform yang memberikan pengembang untuk melakukan pengembangan sesuai dengan yang diharapkannya [10].

Berdasarkan permasalahan yang telah dikemukakan di atas perlu dilakukan penelitian untuk membangun sebuah sistem informasi manajemen ujian pada Jurusan Sistem Informasi Fakultas Teknologi Informasi Universitas Andalas. Aplikasi yang dibangun dapat menjadi bank soal dan mengacak soal yang digunakan untuk masing-masing peserta ujian pada saat ujian berlangsung. Pada saat ujian, aplikasi diakses menggunakan perangkat mobile. Sistem yang dibangun diharapkan mampu menyelesaikan persoalan-persoalan pada objek yang di teliti.

Penelitian ini membatasi soal yang dikelola oleh sistem informasi yang dibangun berupa soal pilihan ganda dan jawaban singkat. Soal jenis pilihan ganda adalah bentuk soal yang menyediakan pilihan jawaban yang bisa dipilih oleh peserta uji. Soal jenis ini bisa mencakup banyak materi dan penilaiannya dapat dilakukan secara objektif. Kelebihan soal jenis ini adalah memiliki waktu koreksi yang relative singkat dan penilaian yang objektif. Namun soal jenis memiliiki peluang kerjasama antar peserta uji yang cukup besar dan sulit untuk membuat soal yang berkualitas. Begitu juga halnya dengan soal jawaban singkat pada mode ujian tertulis.

\section{METODE}

\subsection{Objek Penelitian}

Objek kajian dalam penelitian ini adalah Jurusan Sistem Informasi Fakultas Teknologi Informasi Universitas Andalas. Jurusan Sistem Informasi merupakan salah satu jurusan di Fakultas Teknologi Informasi Universitas Andalas. Jurusan ini didirikan dengan Surat Keputusan Direktur Jenderal Pendidikan Tinggi Departemen Pendidikan Nasional No. 1932/D/T/2009 tanggal 28 Oktober 2009 di bawah Fakultas Teknik. Jurusan Sistem Informasi merupakan jurusan yang terdiri dari 1 program studi yaitu Sistem Informasi.

\subsection{Metode Penelitian}

Penelitian ini berupa pengembangan perangkat lunak. Oleh karena itu metodologi penelitian yang digunakan mengikuti SDLC (Software Development Life Cycle). SDLC merupakan siklus pengembangan perangkat lunak yang meliputi prosedur, langkah, perangkat bantu yang digunakan dalam membangun perangkat lunak. Secara umum SDLC terbagi dalam beberapa 
tahapan planning, modelling dan construction. Ada beberapa varian model proses pengembangan perangkat lunak, salah satu diantaranya adalah model waterfall. Pada model waterfall, setiap proses dilakukan secara bertingkat dari satu tahapan ke tahapan berikutnya [11].

Tahapan penelitian ini ditentukan berdasarkan tahapan pada model pengembangan waterfall, Beberapa tahapan pada flowchart penelitian ini, yaitu studi pendahuluan, studi literatur, pengumpulan data, analisis sistem, pembuatan desain sistem, pengkodean, pengujian sistem, dan pembuatan laporan seperti pada Gambar 1.

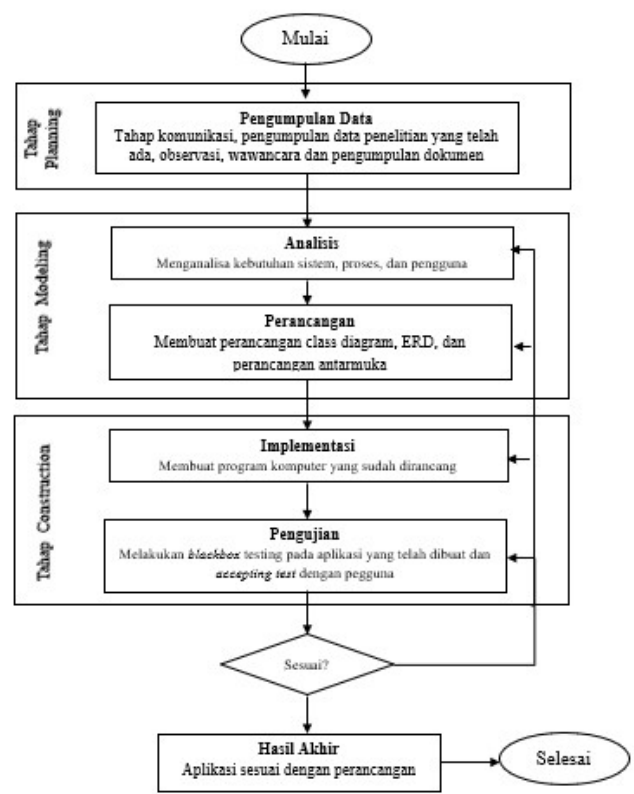

Gambar 1 Tahapan penelitian

\section{ANALISIS DAN PERANCANGAN}

Pada bagian ini dijelaskan tentang tahapan analisis dan perancangan yang dilakukan dalam penelitian ini. Tahapan ini merupakan tahapan awal dalam proses pengembangan sistem. Analisis dilakukan untuk menentukan kebutuhan fungsional sistem yang dibangun. Untuk itu perlu dipahami dan dianalisis terlebih dahulu proses bisnis pengelolaan ujian di jurusan Sistem Informasi saat ini.

\subsection{Analisis Proses Bisnis}

Analisa proses bisnis pengelolaan ujian di Jurusan Sistem Informasi dibatasi pada proses berikut ini:

1. Proses pembuatan soal ujian

2. Proses pelaksanaan ujian

3. Proses tindak lanjut pelanggaran ujian.

4. Proses penilaian ujian.

Proses-proses tersebut akan digambarkan dengan Business Process Modelling Notation (BPMN). BPMN merupakan suatu notasi standar yang dapat berupa ikon atau gambar untuk digunakan di dalam pemodelan proses bisnis[12]. BPMN tidak digunakan untuk pemodelan data tetapi untuk menunjukkan aliran data atau pesan serta asosiasi data kegiatan. Diagram BPMN terdiri dari empat elemen yaitu flow object, connecting objects, artefacts \& data objects, dan swimlanes.
Berdasarkan hasil pengamatan, dan analisis dokumen yang dilakukan, didapatkan diagram BPMN proses pengelolaan ujian berikut ini

a. Proses Pembuatan Soal Ujian

Proses pembuatan ujian merupakan proses yang dilakukan oleh dosen untuk membuat ujian dengan soal ujian tertentu dari materi kuliah yang telah diajarkan. Ujian yang dibuat oleh dosen bisa untuk kuis,ujian harian, UTS maupun UAS. Untuk alur pembuatan soal ujian dapat dilihat pada Gambar 2. Pada proses pembuatan soal ujian memiliki beberapa tahapan sebagai berikut:

1. Dosen mencari terlebih dahulu referensi untuk membuat soal. Referensi ini bisa berupa langsung dari pemahaman dosen dari referensi dari buku.

2. Dosen membuat soal ujian

3. Jika ujian tersebut ditujukan untuk ujian harian atau kuis dosen bisa langsung memperbanyak soal ujiannya dan selesai

4. Jika ujian ditujukan untuk UTS ataupun UAS maka dosen harus meminta verifikasi dari GKM (Gugus Kendali Mutu)

5. Tim GKM memverifikasi soal ujian. Jika telah dinyatakan lulus verifikasi makan dilanjutkan validasi ke ketua prodi jurusan sistem informasi

6. Jika tidak lulus verifikasi maka dosen harus membuat ulang soal ujiannya.

7. Ketua prodi memvalidasi soal ujian. Jika sudah disetujui maka bisa langsung diperbanyak oleh dosen dan jika tidak disetujui maka dosen harus memperbaiki soal tersebut.

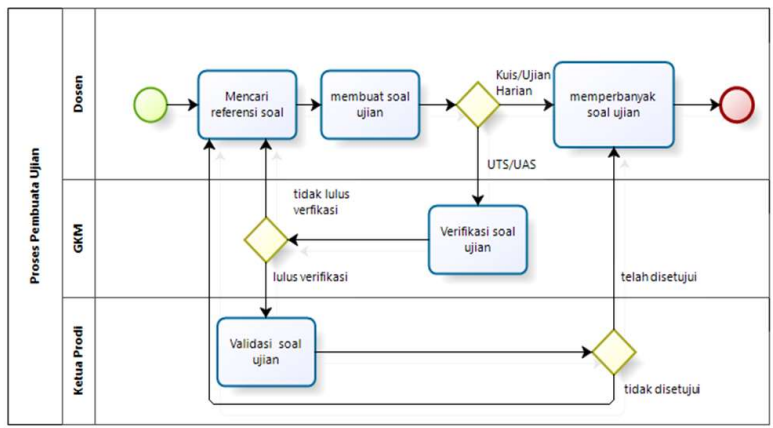

Gambar 2. Diagram BPMN proses pembuatan soal ujian

b. Proses Pelaksanaan Ujian oleh Mahasiswa

Proses ujian yang dilakukan menggunakan kertas sebagai media untuk menuliskan jawaban dari mahasiswa. BPMN untuk proses ini bisa dilihat pada Gambar 3. Pada proses ujian yang sedang berjalan memiliki beberapa tahap:

1. Dosen menjelaskan peraturan-peraturan khusus yang berlaku pada soal ujian mata kuliah tertentu.

2. Dosen memberikan lembar jawaban beserta soal ujian kepada siswa.

3. Selanjutnya mahasiswa menerima lembar jawaban dan soal ujian, mahasiswa diharuskan mengisi biodata yang ada pada lembar jawaban agar memiliki identitas tertentu sehingga mudah diidentifikasi mahasiswa yang bersangkutan.

4. Selanjutnya mahasiswa memberikan lembar jawaban kepada petugas ujian setelah menyelesaikan ujian yang ada sesuai dengan waktu yang ditentukan.

5. Dosen menerima lembar jawaban dari mahasiswa. 


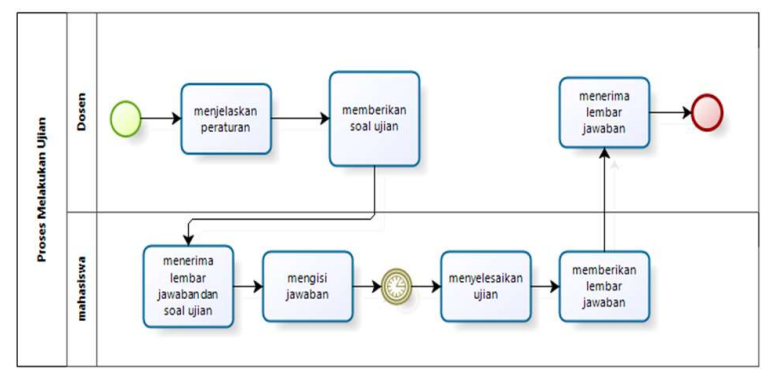

Gambar 3. Diagram BPMN pelaksanaan ujian oleh Mahasiswa

c. Proses Pelanggaran Ujian

Proses pelanggaran ujian merupakan suatu proses yang dilakukan oleh mahasiswa dan dosen ketika mahasiswa melakukan suatu kecurangan pada saat pelaksanaan ujian berlangsung. Alur proses ini dapat dilihat pada Gambar 4. Adapun tahapan pelanggaran ujian adalah sebagai berikut:

1. Mahasiswa terbukti melakukan suatu kecurangan pada saat pelaksanaan ujian berlangsung

2. Dosen menanggapi pelanggaran tersebut. Jika pelanggaran tersebut tergolong ringan maka dosen akan memperingati mahasiswa tersebut agar tidak mengulanginya.

3. Jika pelanggaran mahasiswa tersebut tergolong berat maka lembar ujian mahasiswa akan diambil oleh dosen.

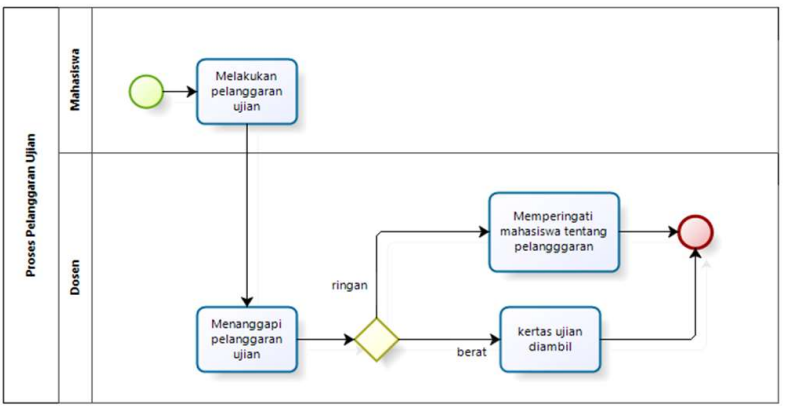

Gambar 4. Diagram BPMN tindak lanjut ujian

\section{d. Proses Penilaian Ujian}

Proses penilaian merupakan proses dilakukan oleh aktor dosen dengan tujuan untuk memberikan penilaian kepada jawaban yang telah dikerjakan mahasiswa. Alur proses penilaian ujian dapat dilihat pada Gambar 5. Adapun tahapan penilaian ujian adalah sebagai berikut:

1. Dosen menerima lembar jawaban ujian mahasiswa.

2. Dosen memeriksa lembar jawaban tersebut dan memberikan nilai secara manual.

3. Dosen merekap nilai dari mahasiswa.

4. Dosen memberikan lembar jawaban ke mahasiswa

5. Mahasiswa menerima lembar jawaban tersebut sebagai bahan evaluasi belajar.

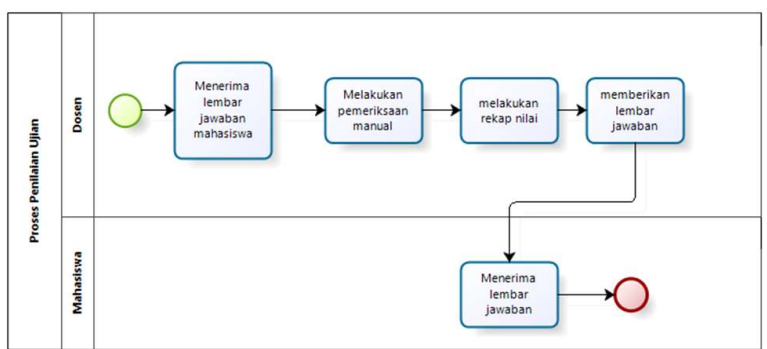

Gambar 5. Diagram BPMN proses penilaian ujian

\subsection{Analisa Kebutuhan Fungsional}

Kebutuhan fungsional merupakan fungsi yang dimiliki oleh sistem yang dibangun. Kebutuhan fungsional harus ditentukan sebelum proses pembangunan sistem dilanjutkan. Berdasarkan analisis alur proses sistem informasi manajemen ujian pada tahapan sebelumnya, dapat dirumuskan beberapa kebutuhan fungsional sistem yang dibangun yaitu:

a. Dosen bisa membuat soal-soal yang akan diujiankan pada mata kuliah yang diampu. Soal yang dibuat akan menjadi bank soal yang bisa digunakan untuk beberapa ujian.

b. Dosen dapat melihat mata kuliah yang diampu beserta kelasnya.

c. Dosen dapat membuat ujian tertentu pada kelas yang diampu.

d. Dosen dapat mengubah status ujian mahasiswa sebagai proses pelanggaran yang dilakukan pada pelaksanaan ujian.

e. Dosen dapat melihat daftar semua ujian yang dibuat.

f. Dosen pengampu kelas dapat melihat semua mahasiswa kelasnya.

g. Dosen pengampu kelas bisa melihat nilai yang diperoleh mahasiswa.

h. Mahasiswa dapat melakukan ujian.

i. Mahasiswa dapat melihat daftar ujian yang ada pada mata kuliah yang diambil.

j. Mahasiswa dapat melihat hasil dari ujian yang dilakukan sebagai proses pelaksanaan ujian

k. Admin dapat mengelola data mahasiswa dan dosen, menambahkan data mahasiswa kelas.

1. Admin jurusan dapat mengelola data mata kuliah.

m. Admin jurusan dapat mengelola data kelas dan mahasiswa yang mengambil kelas mata kuliah tertentu.

n. Ketua prodi bisa kelola validasi ujian

o. Tim GKM bisa kelola verifikasi ujian

p. Semua aktor dalam sistem dapat melakukan login dan logout.

Berdasarkan kebutuhan fungsional yang dibutuhkan oleh user yang telah dianalisis kembali menjadi lebih detail melalui usecase diagram. Use case diagram merupakan rangkaian tindakan yang dilakukan oleh sistem, aktor mewakili user atau sistem lain yang berinteraksi dengan sistem yang dimodelkan [13]. Melalui use case diagram kita dapat mengetahui fungsi-fungsi apa saja yang ada pada sistem [14]. Gambaran usecase diagram pada aplikasi dapat dilihat pada Gambar . 


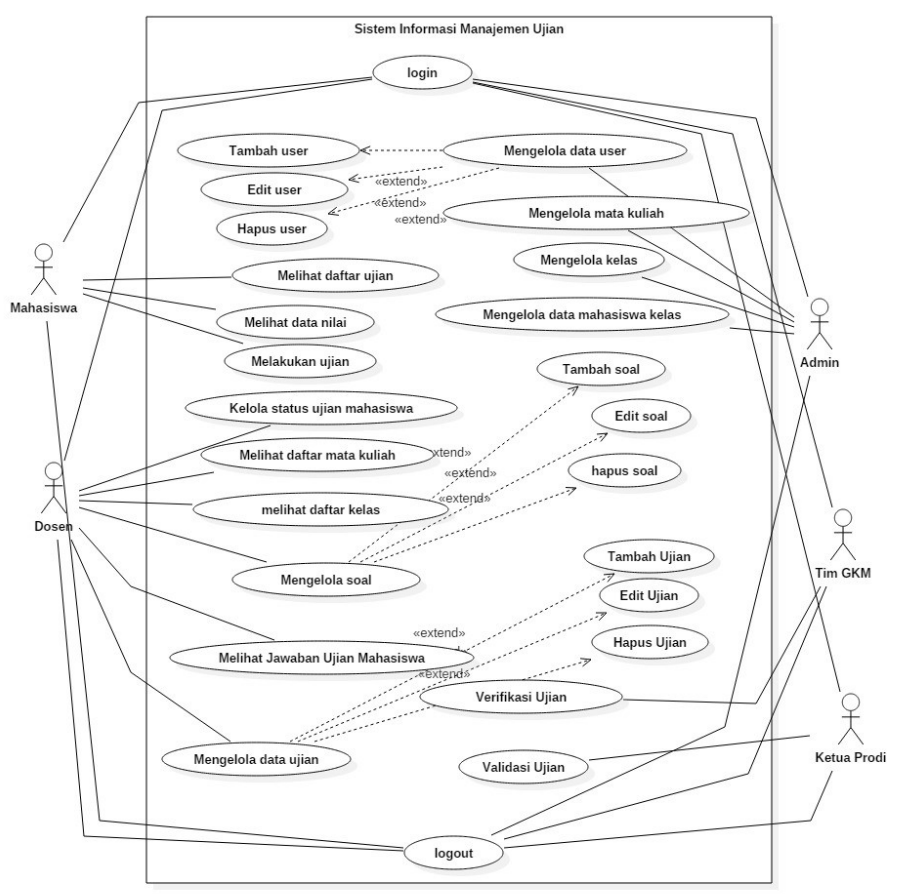

Gambar 6 Usecase Diagram Sistem Informasi Manajemen Ujian

Use case scenario menjabarkan perintah-perintah sistem secara sistematik sehingga harus menghubungkan sistem dan aktor dengan rinci.

Tabel 1. Use case scenario pembuatan soal ujian.

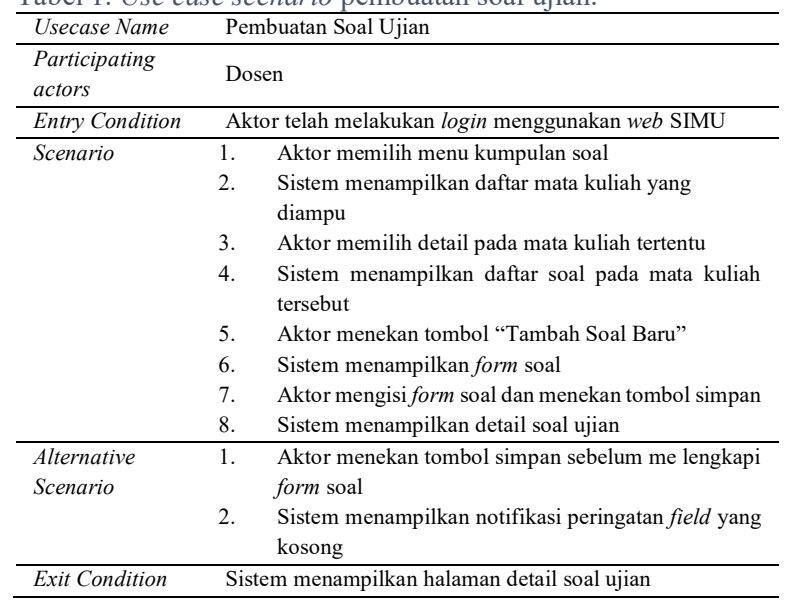

Untuk menggambarkan semua proses yang terjadi di dalam sistem dapat digunakan sequence diagram. Sequence diagram merupakan sebuah diagram yang menunjukkan eksekusi operasi di sebuah objek yang melibatkan pemanggilan operasi di objek lain[13]. Sequence diagram yang ditampilkan dalam jurnal ini hanya salah satunya, yaitu sequence diagram pembuatan soal ujian.

Proses pembuatan soal ujian oleh dosen dimulai dari dosen menekan tombol tambah soal baru controller akan menghubungkan ke tampilan form tambah soal baru. Kemudian dosen mengisi form. Selanjutnya dosen menekan tombol "simpan". Controller menerima perintah untuk menyimpan soal baru. Controller Soal mengirimkan data dari view ke model. Data yang dimasukkan disimpan oleh model ke database. Untuk gambaran lengkap langkah-langkah pada proses pembuatan soal ujian dapat dilihat pada gambar 7 . 


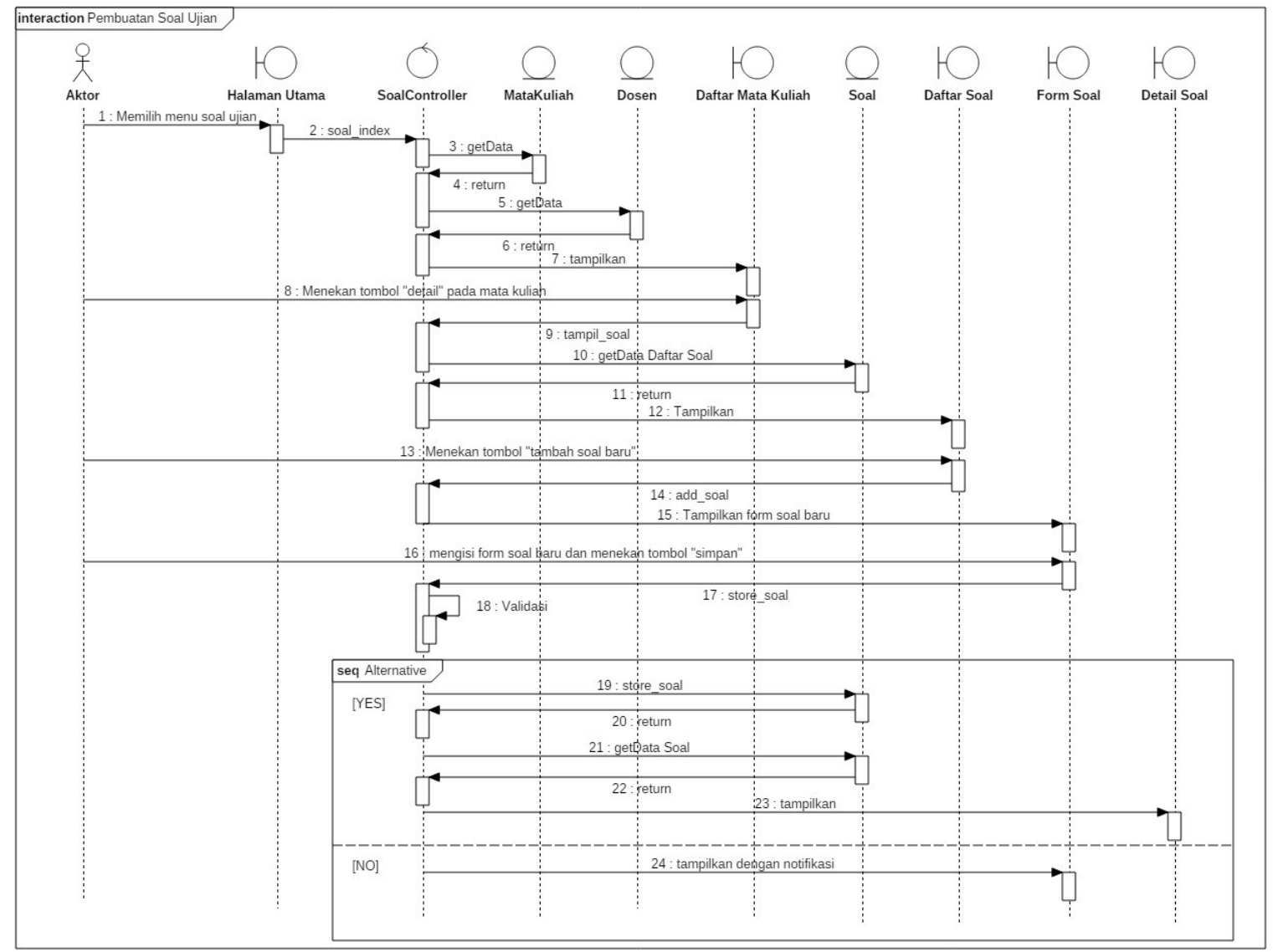

Gambar 7. Sequence Diagram Pembuatan Soal Ujian

\subsection{Perancangan Sistem}

Berdasarkan analisis proses bisnis yang sedang berjalan dan kebutuhan dari sistem informasi yang dibangun diperoleh sebuah perancangan sistem yang menjadi tolak ukur dalam membangun sebuah sistem informasi. Terdapat 4 jenis rancangan yang dihasilkan dalam tahapan perancangan ini yaitu arsitektur sistem, rancangan basis data, rancangan class diagram dan rancangan antarmuka pengguna.

\subsubsection{Arsitektur Aplikasi}

Arsitektur aplikasi adalah sebuah teknologi spesifikasi yang akan digunakan untuk mengimplementasikan sistem informasi. Arsitektur aplikasi menentukan kinerja yang dilakukan client dan server. Sistem ini dibangun dengan menggunakan arsitektur Model-View-Controller (MVC). Arsitektur MVC merupakan arsitektur yang membagi sistem dalam 3 komponen utama yaitu Model, View dan Controller. Rancangan arsitektur aplikasi dapat dilihat pada Gambar .

\subsubsection{Entity Relationship Diagram}

Rancangan berikutnya adalah rancangan database. Database adalah sekumpulan data persisten yang digunakan oleh system aplikasi dari suatu perusahaan. Racnangan database digarmbarkan dengan menggunakan Entity Relationship Diagram (ERD). ERD merupakan teknik yang digunakan untuk memodelkan kebutuhan data dari suatu organisasi, biasanya oleh
Sistem Analis dalam tahap analisis persyaratan proyek pengembangan sistem. Sementara seolah-olah teknik diagram atau alat peraga memberikan dasar untuk desain database relasional yang mendasari sistem informasi yang dikembangkan [15].

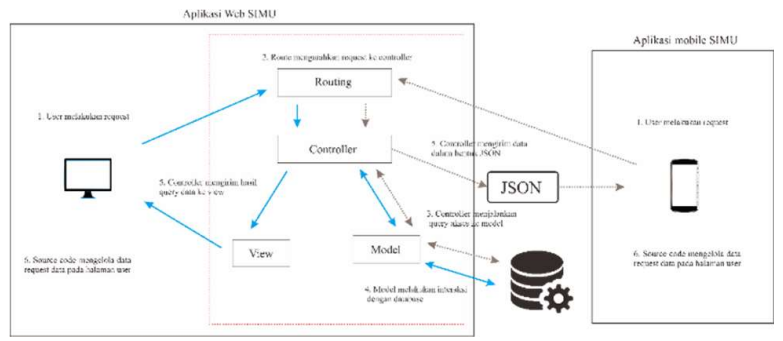

Gambar 8. Arsitektur aplikasi sistem informasi pengelolaan ujian.

Database yang dirancang terdiri dari 18 tabel. Soal ujian disimpan dalam tabel soal, soal_pilihan_ganda, soal_jawaban_singkat dan soal_ujian. Tabel soal_pilihan_ganda dan soal_jawaban_singkat merupakan memiliki relasi spesialisasi dari tabel soal. Ketiga tabel ini berfungsi sebagai bank soal. Selanjutnya untuk ujian sendiri ditampung dalam tabel ujian. Dalam tabel ini terdapat field kode yang kode yang digunakan untuk bisa mengikuti ujian. Selanjutnya tabel ujian ini direlasikan dengan tabel soal melalui tabel pivot soal_ujian. Hal ini dikarenakan sebuah ujian memiliki banyak soal, dan sebuah soal dapat digunakan di berbagai ujian. Rancangan Entity 
Relathionship Database (ERD) selengkapnya dari sistem ini dapat dilihat pada Gambar .

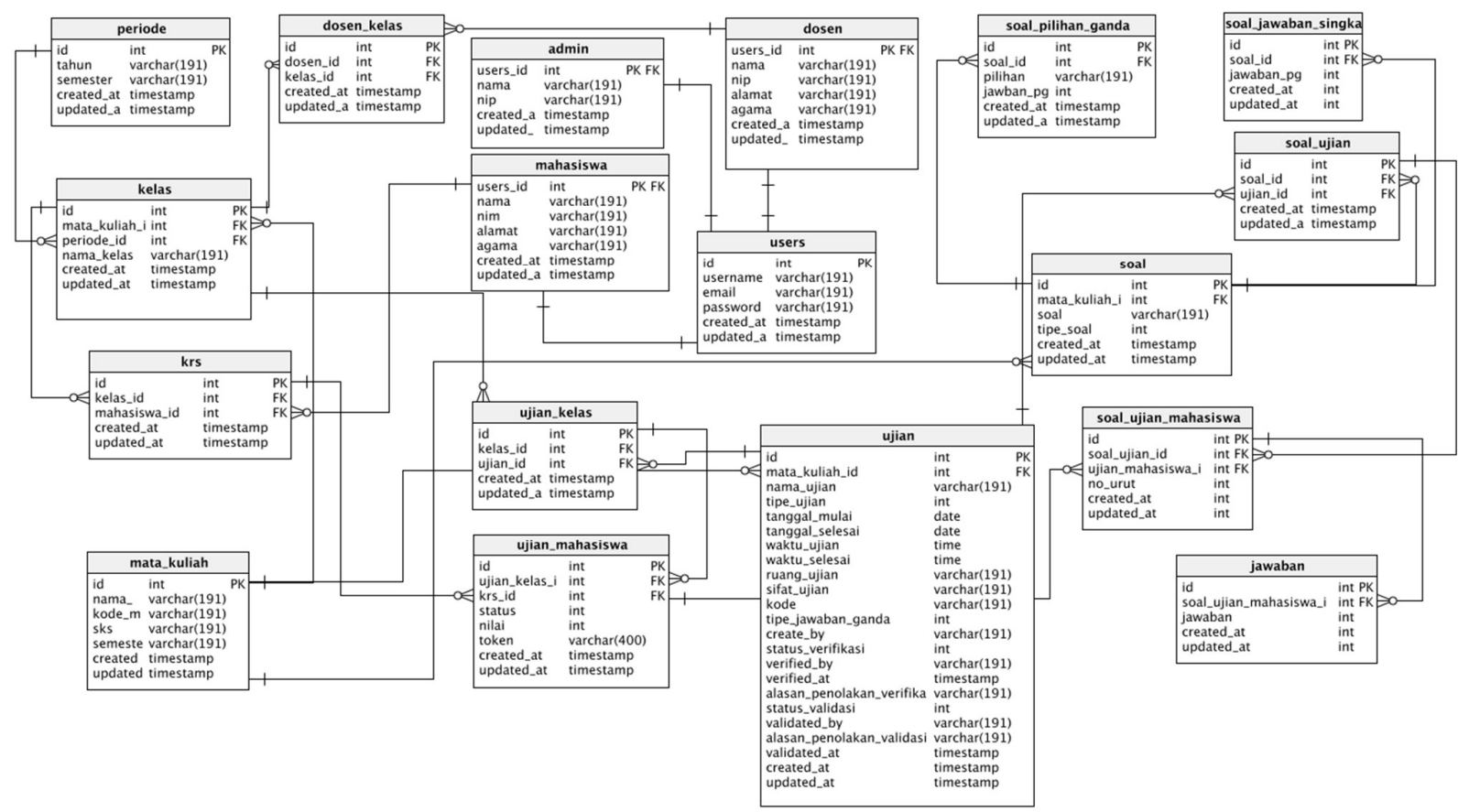

Gambar 9. ERD Sistem Informasi Manajemen Ujian

Rancangan selanjutnya yang dibutuhkan dalam pengembangan sistem ini adalah class diagram. Class diagram menunjukkan komponen-komponen yang terlibat dalam sistem informasi manajemen ujian. Oleh karena arsitektur yang digunakan adalah MVC, maka kelas-kelas yang dirancang dapat digolongkan dalam 3 jenis yaitu Model, View dan Controller. Arsitektur ini sudah memberikan relasi yang jelas dimana View terhubung dengan Controller dan Controller terhubung dengan Model. Namun untuk sistem ini, View tidak diimplementasikan dalam bentuk kelas, melainkan dalam bentuk template html. Rancangan class diagram sistem ini menghasilkan 13 controller dan 18 model.

\subsubsection{Rancangan Antarmuka Pengguna}

Antarmuka mencakup serangkaian tampilan grafis yang dapat dimengerti oleh pengguna atau user dan diprogram sedemikian rupa sehingga dapat terbaca oleh sistem. Dalam sistem informasi manajemen ujian ini terdapat 2 jenis rancangan antarmuka yaitu antarmuka aplikasi web dan antarmuka aplikasi mobile.

Aplikasi web merupakan aplikasi yang digunakan oleh dosen dalam mengelola ujian dan soal ujian yang akan dilaksanakan. Salah satu perancangan antarmuka aplikasi web yang dihasilkan pada tahapan perancangan antarmuka rancangan halaman dashboard dosen seperti pada Gambar dan rancangan antarmuka halaman pengelolaan soal ujian yang dapat dilihat pada Gambar

Aplikasi mobile merupakan aplikasi yang digunakan untuk melaksanakan ujian itu sendiri. Aplikasi ini digunakan oleh mahasiswa dan dosen. Rancangan tampilan aplikasi mobile untuk mahasiswa dapat dilihat pada Gambar . Bagi mahasiswa aplikasi mobile digunakan untuk mengikuti ujian sehingga dibutuhkan antarmuka daftar ujian yang diikuti beserta informasinya seperti jadwal dan nilai yang telah diraih dan juga tampilan daftar soal yang akan dijawab dalam ujian. Bagi dosen

164 Husnil Kamil

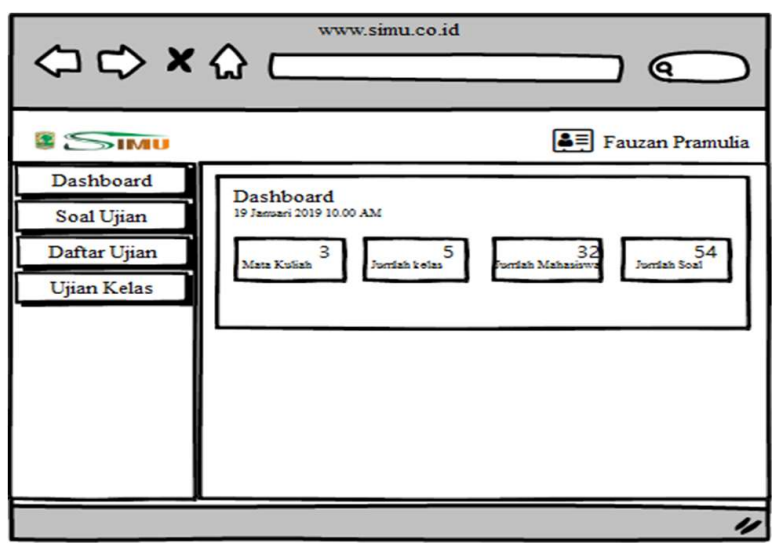

Gambar 10. Rancangan antarmuka dashboard dosen

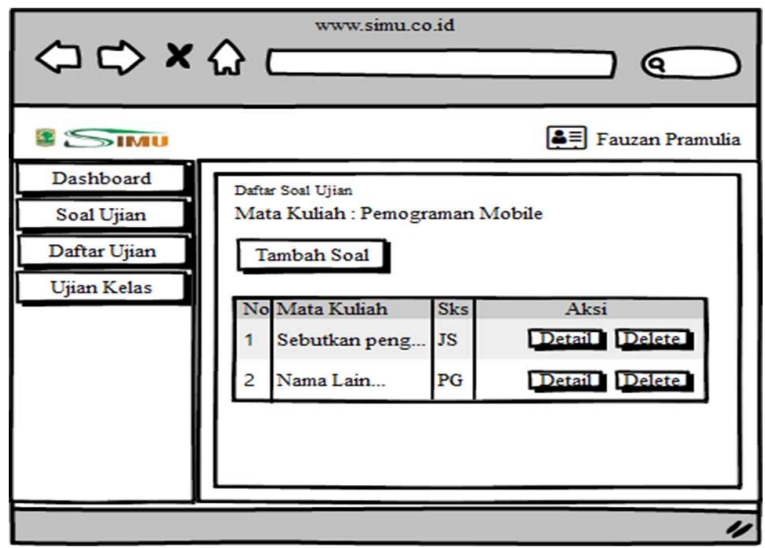

Gambar 11. Rancangan halaman pengelolaan soal ujian 


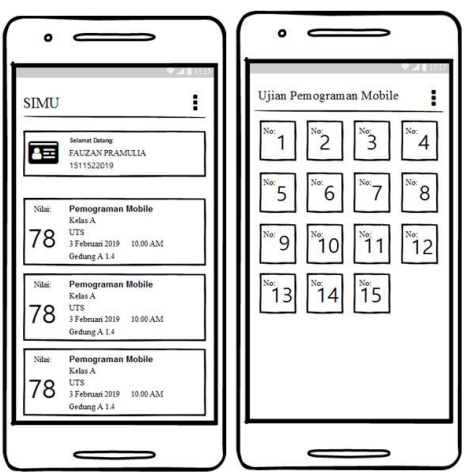

Gambar 12. Rancangan antarmuka aplikasi mobile untuk mahasiswa

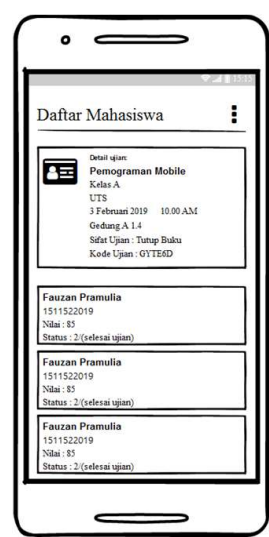

Gambar 13. Rancangan antarmuka aplikasi mobile untuk dosen

\section{HASIL DAN PEMBAHASAN}

\subsection{Implementasi Sistem}

Rancangan sistem yang telah dihasilkan pada tahapan sebelumnya diimplementasikan ke dalam bentuk sistem informasi melalui proses pengkodean. Untuk aplikasi web, sistem informasi manajemen ujian ini diimplementasikan dengan menggunakan bahasa pemrograman PHP. Untuk mempercepat proses pengembangan, aplikasi web dibangun dengan menggunakan framework Laravel 5.7. Tampilan hasil implementasi aplikasi web sistem informasi manajemen ujian untuk halaman dashboard dosen dan halaman pengelolaan hasil ujian dapat dilihat pada Gambar dan Gambar .
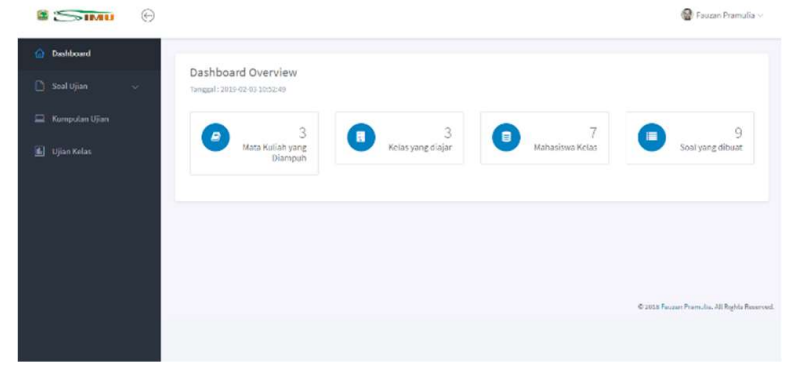

Gambar 14. Tampilan halaman dashboard dosen.

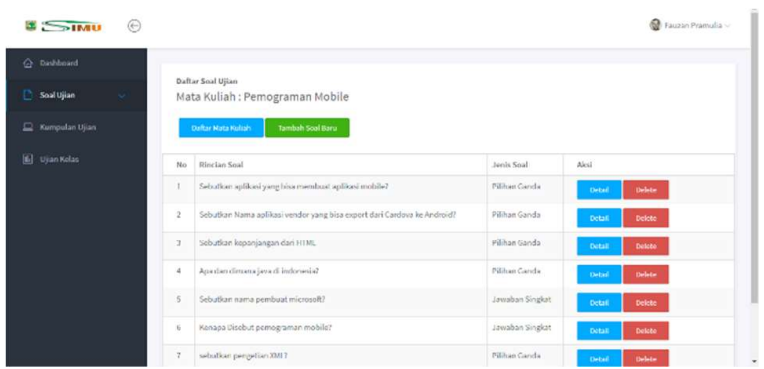

Gambar 15. Tampilan halaman pengelolaan soal ujian pada aplikasi web

Aplikasi mobile manajemen ujian digunakan oleh 2 user yaitu dosen dan mahasiswa. Aplikasi mobile dibangun dengan menggunakan bahasa pemrograman Java dan perangkat yang digunakan adalah Android Studio versi 3.1.3. Tampilan halaman aplikasi mobile untuk pengguna mahasiswa dapat dilihat pada Gambar. Gambar (a) menampilkan tampilan halaman daftar ujian yang akan diikuti oleh mahasiswa sedangkan Gambar 16 (b) menampilkan daftar soal yang harus dijawab oleh mahasiswa saat mengikuti ujian. Tampilan halaman aplikasi mobile untuk pengguna mahasiswa dapat dilihat pada Gambar . Pada Gambar , dosen dapat melihat mahasiswa yang mengikuti ujian yang diselenggarakan.

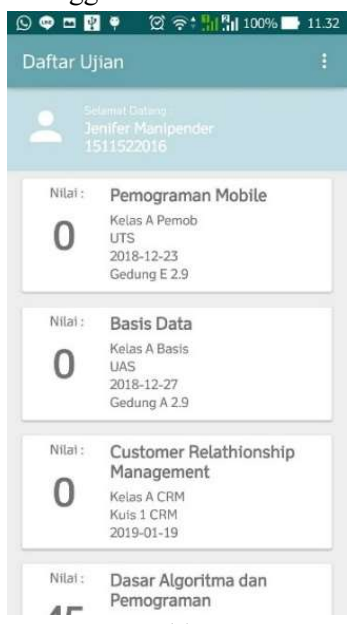

(a)

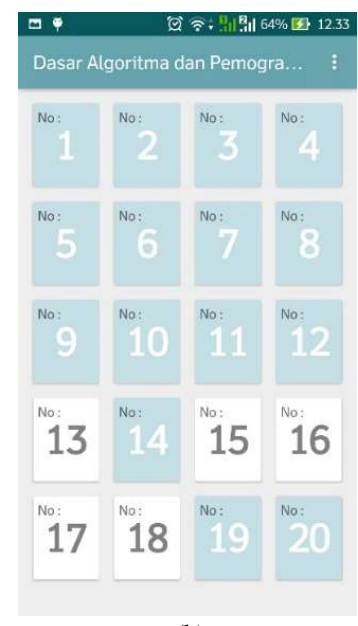

(b)
Gambar 16. Tampilan implementasi aplikasi mobile untuk pengguna mahasiswa

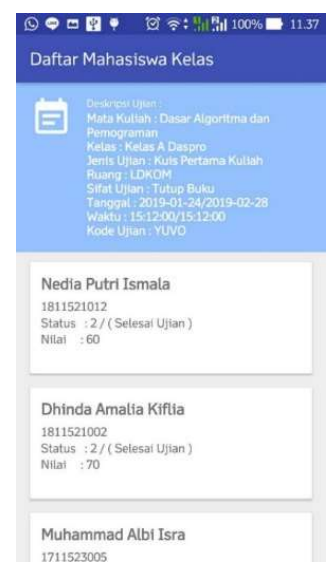

Gambar 17. Tampilan aplikasi mobile ujian untuk pengguna dosen 
Untuk memulai sebuah ujian, mahasiswa harus menginputkan kode ujian yang telah ditentukan oleh dosen pengampu. Kode ujian ini diberikan oleh dosen pengampu sebelum ujian. Penggunaan kode ujian ini ditujukan untuk mencegah mahasiswa melaksanakan ujian di luar waktu dan tempat yang telah ditentukan. Tampilan input kode ujian oleh mahasiswa dapat dilihat pada Gambar .

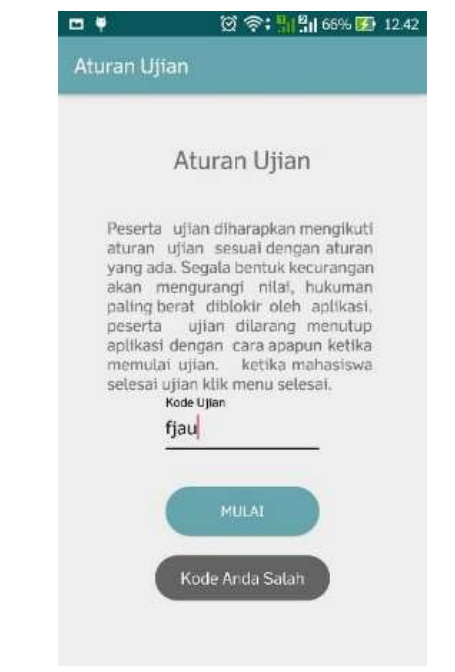

Gambar 18. Tampilan input kode ujian

\subsection{Pengujian Sistem}

Pengujian sistem dilakukan menggunakan metode Black Box Testing yang dilakukan dengan cara mengamati hasil eksekusi melalui data uji dan memeriksa fungsional dari perangkat lunak. Fokus pengujian aplikasi berdasarkan kebutuhan fungsional yang telah didapatkan sebelumnya. Hasil pengujian yang telah dilakukan dapat dilihat pada Tabel . Berdasarkan hasil pengujian tersebut dapat disimpulkan bahwa Sistem Informasi Manajemen Ujian pada Jurusan Sistem Informasi Universitas Andalas telah berjalan sesuai dengan fungsional yang dirancang.

Dari 19 fokus pengujian yang diuji, 19 item pengujian menunjukkan kesesuaian fungsional dengan sistem yang dibangun. Berdasarkan hasil tersebut dapat disimpulkan bahwa aplikasi Sistem Informasi Manajemen Ujian telah sesuai dengan perancangan yang ada. Adapun hasil yang dibangun memiliki beberapa fitur yang berguna untuk menunjang proses pengadaan ujian yang terintegrasi di dalam sistem ini sebagai berikut:

1. Aplikasi memudahkan admin dalam pengelolaan user.

2. Aplikasi dapat melakukan pelaksanaan ujian secara efisien dan efektif.

3. Aplikasi dapat menghitung total mahasiswa kelas yang tersedia dalam bentuk dashboard user/dosen.

4. Aplikasi dapat mempermudah dalam pengelolaan mata kuliah.

5. Soal ujian yang dibuat bisa digunakan untuk beberapa ujian.

6. Dosen bisa melakukan pengubahan status ujian mahasiswa jika mahasiswa melakukan kecurangan ujian.
Tabel 2. Hasil pengujian sistem.

\begin{tabular}{|c|c|c|c|c|}
\hline No & Item Uji & $\begin{array}{c}\text { Jenis } \\
\text { Aplikasi }\end{array}$ & $\begin{array}{c}\text { Detail } \\
\text { Pengujian }\end{array}$ & Hasil \\
\hline 1 & Autentikasi & $\begin{array}{l}\text { Web, } \\
\text { Mobile }\end{array}$ & $\begin{array}{l}\text { Login, } \\
\text { Logout }\end{array}$ & Sesuai \\
\hline 2 & $\begin{array}{ll}\text { Kelola } & \text { data } \\
\text { mahasiswa } & \end{array}$ & $W e b$ & $\begin{array}{c}\text { Lihat, } \\
\text { Tambah, } \\
\text { Edit, Hapus }\end{array}$ & Sesuai \\
\hline 3 & Kelola data dosen & Web & $\begin{array}{c}\text { Lihat, } \\
\text { Tambah, } \\
\text { Edit, Hapus }\end{array}$ & Sesuai \\
\hline 4 & $\begin{array}{l}\text { Kelola data mata } \\
\text { kuliah }\end{array}$ & Web & $\begin{array}{c}\text { Lihat, } \\
\text { Tambah, } \\
\text { Edit, Hapus }\end{array}$ & Sesuai \\
\hline 5 & Kelola data kelas & $\overline{W e b}$ & $\begin{array}{c}\text { Lihat, } \\
\text { Tambah, } \\
\text { Edit, Hapus }\end{array}$ & Sesuai \\
\hline 6 & $\begin{array}{l}\text { Kelola data } \\
\text { mahasiswa kelas }\end{array}$ & $W e b$ & $\begin{array}{c}\text { Lihat, } \\
\text { Tambah, } \\
\text { Edit, Hapus }\end{array}$ & Sesuai \\
\hline 7 & $\begin{array}{l}\text { Kelola status ujian } \\
\text { mahasiswa }\end{array}$ & Mobile & $\begin{array}{c}\text { Lihat, } \\
\text { Tambah, } \\
\text { Edit, Hapus }\end{array}$ & Sesuai \\
\hline 8 & $\begin{array}{l}\text { Melihat daftar } \\
\text { mata kuliah }\end{array}$ & Web & Lihat & Sesuai \\
\hline 9 & $\begin{array}{l}\text { Melihat daftar } \\
\text { kelas }\end{array}$ & $W e b$ & Lihat & Sesuai \\
\hline 10 & $\begin{array}{l}\text { Kelola data soal } \\
\text { ujian }\end{array}$ & $W e b$ & $\begin{array}{c}\text { Lihat, } \\
\text { Tambah, } \\
\text { Edit, Hapus }\end{array}$ & Sesuai \\
\hline 11 & Kelola data ujian & $W e b$ & $\begin{array}{c}\text { Lihat, } \\
\text { Tambah, } \\
\text { Edit, Hapus }\end{array}$ & Sesuai \\
\hline 12 & $\begin{array}{l}\text { Melihat nilai } \\
\text { mahasiswa kelas }\end{array}$ & Mobile & Lihat & Sesuai \\
\hline 13 & $\begin{array}{l}\text { Melihat daftar } \\
\text { ujian kelas }\end{array}$ & $\begin{array}{c}\text { Web, } \\
\text { Mobile }\end{array}$ & Lihat, Detail & Sesuai \\
\hline 14 & $\begin{array}{ll}\text { Melihat daftar } \\
\text { ujian kelas }\end{array}$ & Mobile & Lihat & Sesuai \\
\hline 15 & Melihat nilai ujian & Mobile & Lihat & Sesuai \\
\hline 16 & Melakukan ujian & Mobile & $\begin{array}{c}\text { Lihat, } \\
\text { Tambah, } \\
\text { Edit, Hapus }\end{array}$ & Sesuai \\
\hline 17 & Melihat soal ujian & Mobile & Lihat & Sesuai \\
\hline 18 & $\begin{array}{l}\text { Memverifikasi } \\
\text { Ujian }\end{array}$ & $\begin{array}{c}\text { Web, } \\
\text { Mobile }\end{array}$ & $\begin{array}{c}\text { Lihat, Edit, } \\
\text { Hapus }\end{array}$ & Sesuai \\
\hline 19 & $\begin{array}{l}\text { Memvalidasi } \\
\text { Ujian }\end{array}$ & $\begin{array}{c}\text { Web, } \\
\text { Mobile }\end{array}$ & $\begin{array}{l}\text { Lihat, Edit, } \\
\text { Hapus }\end{array}$ & Sesuai \\
\hline
\end{tabular}

\section{KESIMPULAN}

Aplikasi Sistem Informasi Manajemen Ujian pada Jurusan Sistem Informasi Universitas Andalas, telah berhasil dibangun menggunakan metode waterfall. Terdapat 4 proses pengelolaan ujian di jurusan sistem informasi. Berdasarkan analisis proses tersebut didapatkan 15 fungsional sistem dan berhasil mengidentifikasi 5 aktor, yaitu admin, ketua prodi, dosen, tim GKM dan mahasiswa. Hasil pengujian sistem ini menunjukkan bahwa sistem yang dibangun telah sesuai dengan kebutuhan fungsional sistem yang telah ditentukan sebelumnya.

Aplikasi Sistem Informasi Manajemen Ujian ini masih membutuhkan pengembangan lebih lanjut yang sesuai dengan kebutuhan fungsional. Diharapkan aplikasi ini dapat dikembangkan dengan menambah fungsi-fungsi yang lebih 
lengkap. Saran terhadap pembangunan aplikasi adalah adanya fungsional yang bisa mendeteksi bahwa yang sedang melaksanakan ujian adalah orang yang memang berhak untuk ujian. Sehingga tingkat keamanan dalam penggunaan aplikasi bisa lebih baik lagi kedepannya.

\section{DAFTAR PUSTAKA}

[1] B. Rosner and L. J. Cronbach, "Essentials of Psychological Testing," Am. J. Psychol., 1960, doi: 10.2307/1419921.

[2] ARNOLD and M. Irmina, "Rancang Bangun Sistem Berbasis Web Modul Bank Soal dan Generator Soal," Progr. Stud. Tek. Inform. Fak. Teknol. Inf. dan Komun. Univ. Multimed. Nusant., 2010.

[3] D. T. Wagner, A. Rice, and A. R. Beresford, "Device analyzer: Understanding smartphone usage," in Lecture Notes of the Institute for Computer Sciences, SocialInformatics and Telecommunications Engineering, LNICST, 2014, doi: 10.1007/978-3-319-11569-6_16.

[4] A. Barel, "Your Smartphone vs. Your PC," 2017. [Online]. Available: https://medium.com/startuxnet/smartphones-will-replace-pcs-soon-541b5c8a4f48. [Accessed: 01-Apr-2019].

[5] J. Potts, N. Moore, and S. Sukittanon, "Developing mobile learning applications for electrical engineering courses," in Conference Proceedings - IEEE SOUTHEASTCON, 2011, doi: 10.1109/SECON.2011.5752952.

[6] R. Davidrajuh, "Java Bluetooth Wireless Technology for Evaluating Student Performance in Classroom," Citeseer, 2005.

[7] J. Lu, A. Sundaram, Z. Meng, P. A, G. Lu, and J. B. Stav, "Mobile Exam System - MES," in Learning with Mobile Technologies, Handheld Devices, and Smart Phones, 2012, pp. 1-20.

[8] M. H. Syahbani, "Pembangunan Aplikasi Simulasi Ujian Berbasis Aplikasi Perangkat Bergerak," vol. 2, no. 1, pp. 251-255, 2016.

[9] (IDC) International Data Corporation, "IDC: Smartphone OS Market Share," Www.Idc.Com, 2015. [Online]. Available: http://www.idc.com/prodserv/smartphone-os-marketshare.jsp. [Accessed: 02-Dec-2018].

[10] Nazruddin Safaat H, Android: Pemrograman Aplikasi Mobile Smartphone dan Tablet PC Berbasis Android (Edisi Revisi). 2012.

[11] Ian Sommerville, Software Engineering (Ninth Edition). 2010.

[12] J. Jeston and J. Nelis, Business Process Management Practical Guidelines to Successful Implementations. 2015.

[13] J. W. Satzinger, R. B. Jackson, and S. D. Burd, Systems analysis and design in a changing world. Cengage learning, 2011.

[14] M. Shalahuddin and A. S. Rosa, "Rekayasa Perangkat Lunak Struktur Dan Berorientasi Objek," Inform. Bandung, Bandung, 2015.

[15] M. Brady and J. Loonam, "Exploring the use of entityrelationship diagramming as a technique to support grounded theory inquiry," Qual. Res. Organ. Manag. An Int. J., vol. 5, no. 3, pp. 224-237, 2010. 